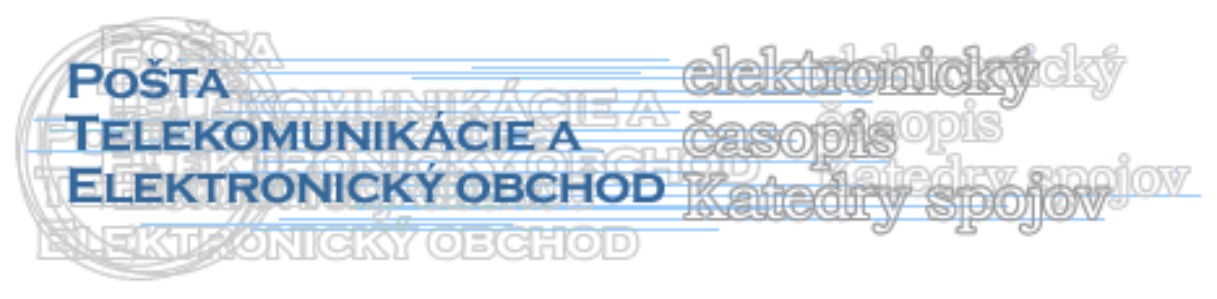

\title{
ŠIROKOPÁSMOVÝ PRÍSTUP V SLOVENSKEJ REPUBLIKE - KOMUNIKAČNÁ INFRAŠTRUKTÚRA
}

\author{
Juraj Fabuš*
}

\section{Úvod}

Séria článkov vzniká za účelom vysvetlenia a objasnenia pojmu širokopásmový prístup, hlavnou témou tohto článku bližšie vysvetlenie stavu v budovaní a využívaní komunikačnej infraštruktúry pre širokopásmový prístup v SR.

Zverejnenie práce je $\mathrm{z}$ dôvodu obšírnosti problematiky rozdelené do viacerých článkov, ktoré budú postupne publikované $\mathrm{v}$ tomto elektronickom časopise. V predchádzajúcej časti boli vysvetlené základné pojmy z predmetnej oblasti, charakterizované jednotlivé služby, ako aj význam a výhody uplatnenia širokopásmového prístupu, nasledovat' bude porovnanie so stavom v EU, ako aj návrh opatrení, ktoré napomôžu k rozšíreniu využívania širokopásmového prístupu pre všetkých obyvatel'ov SR.

Ciel'om je zvýšit' povedomie o širokopásmovom prístupe, zvýšit' záujem o jeho využívanie, čo bude mat' konečný vplyv aj na postavenie Slovenska v rámci EÚ, kde sme medzi členskými krajinami na poslednom mieste vo využívaní širokopásmového prístupu. Články sú určené všetkým, ktorí širokopásmové služby už využívajú, ale aj pre tých, ktorí sa s nimi ešte len zoznamujú.

\section{Prenos informácií na dial'ku}

Telekomunikačná siet' je tvorená siet'ou prenosovou (transportnou), ktorá prepája medzi sebou uzly obsluhy a ústredne, a siet'ou prístupovou (účastníckou), ktorá umožňuje pripojenie jednotlivých účastníkov k uzlom obsluhy. Obe tieto siete boli pôvodne vybudované skoro výhradne na metalických prenosových prostriedkoch (predovšetkým na medených vedeniach) a využívali sa na prenos hovorových kanálov zo šírkou pásma len 3100 Hz.[1]

Tzv. „úzkym“ miestom pri prenose zvýšeného objemu informácii sa stáva prístupová siet'. Prístupová siet', ktorá tvorí posledný úsek medzi účastníkom a obslužným uzlom, niekedy nazývaná aj ,,posledná míla,,, bola pôvodne budovaná výhradne na svoj účel, a to na prenos nízkofrekvenčného signálu medzi účastníkom a jeho prípojnou ústredňou, čo sa nazýva hlasová služba. Táto siet' je tvorená skrúcanými medenými pármi. Odhaduje sa, že až 97\% bytových zákazníkov a podnikatel'ských staníc je pripojených na pevnú siet' skrúcanými medenými pármi. Aj ked' boli vyvinuté a nasadené do praxe niektoré nové moderné princípy

\footnotetext{
* Ing. Juraj Fabuš, PhD., Žilinská univerzita v Žiline, Fakulta prevádzky a ekonomiky dopravy a spojov, Katedra Spojov, Univerzitná 1, 01026 Žilina, Slovenská republika, tel.: +421 908171 890, E-mail: juraj.fabus@fpedas.uniza.sk
} 
riešenia prístupových sieti už na podklade nových systémov s optickými vláknami alebo systémov pevného rádiového prístupu, zostávajú stále $\mathrm{z}$ dôvodov využitia obrovského množstva informácii v zemi.

Operátori potrebujú rozvinutú siet'ovú architektúru, aby mohli používatel'om poskytovat' pripojenie $\mathrm{k}$ službám $\mathrm{z}$ akéhokol'vek zariadenia, bez ohl'adu na miesto, kde sa nachádzajú. Pre užívatel'ov je komfort kl'účový faktor: konvergované služby musia byt' nepretržite dostupné zo všetkých zariadení a sietí. Je potrebné, aby operátori pri zavádzaní nových služieb a dodatočnej siet’ovej kapacity vynakladali minimálne náklady na ich výstavbu a prevádzku. Práve toto umožní znižovanie cien služieb pre užívatel'ov.

Prístupové siete sa nebudujú, pretože je to ekonomicky náročné. Za nevyhnutné sa považuje priama podpora zo strany verejného sektora pri budovaní širokopásmového prístupu, lebo súčasné siete svojou kapacitou, technologickým riešením a technickými parametrami pre širokopásmový prístup vyhovujú len čiastočne.

\section{Súčasný stav širokopásmového prístupu v SR}

Súčasný stav v prístupe k informáciám prostredníctvom internetu je možné považovat' za neuspokojivý, v porovnaní s vyspelými krajinami EÚ.

Hlavnou príčinou takéhoto stavu nie je fyzická nedostupnost' prístupu k internetu, ale najmä nízka kúpna sila obyvatel'stva v porovnaní s cenou počítača a cenou pripojenia k internetu a taktiež nízka motivácia užívatel'ov zriadit' si takýto prístup. Nízka motivácia je zase dôsledkom nízkej informačnej gramotnosti, ktorá by podnecovala motiváciu na využívanie internetu a čiastočne aj $\mathrm{z}$ nedostatku užívatel'sky atraktívnych informačných služieb.

V súvislosti s nerovnomerným rozdelením širokopásmového prístupu sa spája pojem digitálne rozdelenie, resp. digitálna priepast', čo znamená obrovské rozdiely medzi jednotlivými krajinami, regiónmi, podnikmi, domácnost’ami alebo jednotlivcami na rozdielnej socioekonomickej úrovni, spôsobené nerovnakými možnostami prístupu k informačným a komunikačným technológiám a ich efektívnemu využívaniu. Jednotlivé rozdelenia širokopásmového prístupu k internetu podl'a rýchlosti zobrazuje obrázok č. 1.

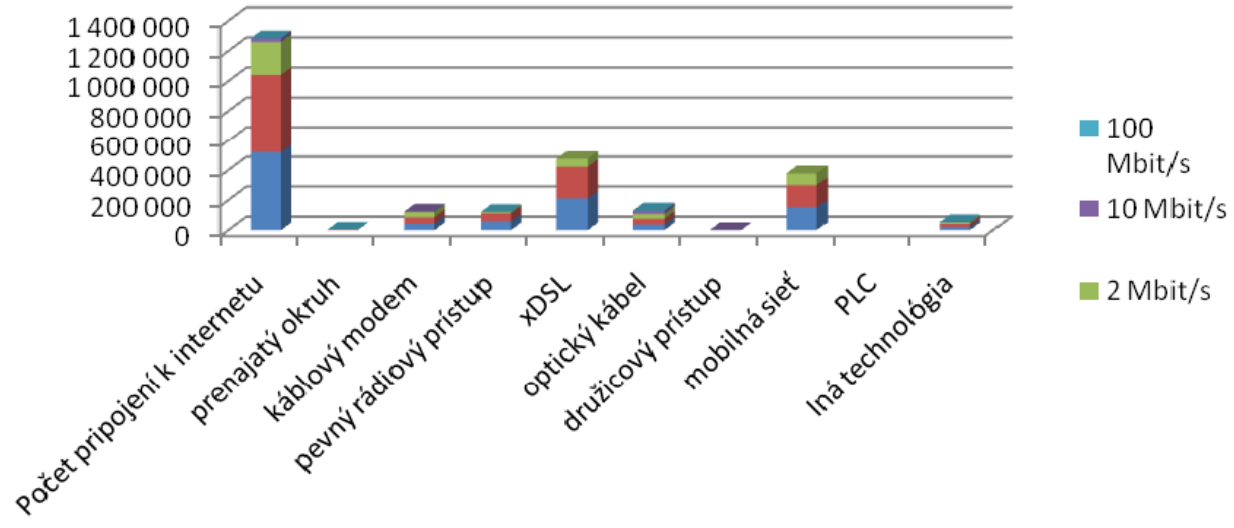

Obrázok č. 1: Širokopásmový prístup k internetu- rozdelenie podla rýchlostí

Dostupné na: <http://www.telecom.gov.sk/externe/telekom /statistika/index.htm> 
Situácia širokopásmového prístupu na Slovensku sa vyznačuje:

- Široká digitálna priepast' - hrozba spočíva v tom, že sa vytvára digitálna priepast' nielen oproti vyspelým štátom, ale aj vo vnútri štátu, medzi l'ud'mi rôzneho sociálneho- ekonomického statusu- majetku, vzdelania, a iné. Paradoxne, teda, prístup na internet l'udí spája, no súčasne, absencia prístupu vytvára medzi l'ud'mi neprekonatel'né bariéry.

- Súčasná ponuka pripojenia - v súčasnosti sa ponuka pripojenia opiera vo väčšine o široko rozšírené technológie, najmä telekomunikačné siete pevné a mobilné a TV káblové rozvody. Nové technológie si vyžadujú v počiatku vybudovanie vlastnej prístupovej technológie.

- Problémy rozvoja pripojení - sú nimi: nerozvinutá infraštruktúra, nerozvinuté trhové prostredie, nedostatočné využívanie súčasných potenciálov a pod.

Rôzne štúdie zdôrazňujú vo všeobecnosti význam širokopásmových služieb pre ekonomický rozvoj, pričom zároveň poukazujú na možnú hrozbu dôsledkov zaostávania práve štátu $\mathrm{v}$ tejto oblasti.

Technológie širokopásmového prístupu a ich technicko-ekonomické parametre výrazne ovplyvňujú rýchlost' a rozsah rozvoja širokopásmových služieb. Vol'ba optimálnej stratégie podpory rozvoja širokopásmového prístupu v Slovenskej republike vyžaduje zohl'adnenie globálnych svetových trendov a tiež výrazných rozdielov vývoja $v$ jednotlivých štátoch ovplyvnených špecifickými podmienkami.[2]

V súčasnosti sú na Slovensku dostupné tieto technológie širokopásmového prístupu:

- xDSL (najmä ADSL) - širokopásmový prístup cez klasickú telefónnu prípojku;

- káblový modem - umožňujúci širokopásmový prístup cez infraštruktúru rozvodov káblovej televízie;

- pevný bezdrôtový prístup (FWA) - umožňujúci širokopásmový prístup prostredníctvom rádiového prenosového systému;

- družicový prístup - umožňujúci širokopásmový prístup prostredníctvom družice;

- optické siete - umožňujúce prakticky neobmedzenú kapacitu a spol’ahlivost' a vysokú kvalitu prenosu;

- mobilné siete tretej generácie (3G siete) - umožňujúce širokopásmový prístup pomocou mobilného telefónu;

- siete interaktívnej digitálnej TV - umožňujúce širokopásmový prístup pomocou set-top boxu.

\section{Technológia xDSL}

Technológie xDSL tvorili v roku 2004 najväčší podiel na rozvoji širokopásmového prístupu, asi $64 \%$ celosvetového počtu širokopásmových prípojok. xDSL technológia vytvára digitálnu účastnícku linku na poskytovanie širokopásmových služieb prostredníctvom symetrického metalického vedenia a technológie xDSL využivajú na prenos digitálneho signálu existujúcu infraštruktúru metalických symetrických káblových vedení prístupových sietí.

Existuje niekol'ko modifikácií xDSL ako: HDSL, SDSL, ADSL, VDSL atd'., z ktorých najrozšírenejšou je ADSL, ktorá umožňuje realizovat' širokopásmový prístup účastníka 
pevnej verejnej telefónnej siete po jeho účastníckom vedení so súčasným a nezávislým poskytovaním klasickej telefónnej služby, alebo základného prístupu ISDN.

Nedostatkom využívania technológií xDSL sú vzájomné presluchy medzi vedeniami toho istého kábla, ktoré obmedzujú počet vedení využitel’ných práve na prenos signálov xDSL. Všeobecne sa využívanie technológií xDSL považuje najmä za prostriedok na efektívne využívanie existujúcich metalických vedení a za technologickú etapu prechodu k poskytovaniu širokopásmových služieb prostredníctvom optických vedení.

\section{Technológia Fixed Wireless Access (FWA)}

FWA technológia pracuje na základe bezdrôtového prepojenia základňovej stanice s viacerými koncovými stanicami (terminálmi) umiestnenými na strane zákazníka. Je vhodná na pripojenie užívatel'ov ako sú malé spoločnosti, ktoré majú vybudované lokálne siete malého rozsahu, pretože pre pripojenie domácností je príliš nákladná.

Tento spôsob prenosu sa hodí najmä v mestských aglomeráciách alebo $\mathrm{v}$ husto osídlených vidieckych oblastiach. Jeho výhodou je vytváranie bunkovej štruktúry, pričom každá bunka obsahuje bázovú stanicu a užívatel'ské terminály, ktoré sú umiestnené v dosahu bázovej stanice.

FWA využíva frekvenčné pásmo 3,5 GHz pre prevádzkovanie MMDS (Multichannel Multipoint Distribution System) a frekvenčné pásmo $26 \mathrm{GHz}$ (prípadne 10 resp. $43 \mathrm{GHz}$ ) pre prevádzkovanie LMDS (Local Multipoint Distribution System).

Na Slovensku už je momentálne možné využívat' na FWA obidve hlavné frekvenčné pásma: $26 \mathrm{GHz}$ a 3,5 GHz. Aj ked' sú obe pásma podobné, ich rozdielnost' je hlavne v nosných technológiách, ktoré sú pre ne určené. FWA $26 \mathrm{GHz}$ sa vzhl'adom na potrebu priamej viditel'nosti, malý dosah od bázovej stanice a vysokej stabilite spojenia oplatí kvôli cene iba pre stredné a hlavne pre väčšie spoločnosti. Naopak FWA 3,5 GHz je pre domácich používatel'ov a malé firmy, práve pre možnost' komunikácie bez priamej viditel'nosti.

FWA pokrytie je od 3 do $5 \mathrm{~km}$ od základňovej stanice. Základom takejto siete je bázová stanica skladajúca sa zo sektorových antén, z ktorých každá vyžaruje na určitý smer čím pokrýva okolie tejto stanice. Na tento centrálny bod sa „pripájajúc klientske zariadenia. Podobne ako to je aj pri WiFi.

\section{Družicový prístup}

Ide o osobitnú kategóriu bezdrôtového prístupu určenú najmä pre osobitne t'ažko prístupné miesta, resp. regióny. Nevýhodou technológie je vysoká finančná náročnost' obojsmerného spojenia (pre pomalší smer prenosu od užívatel'a, t.j. pre upstream sa preto využíva aj existujúca pozemná siet'). Slabým miestom družicového prístupu môže byt' aj závislost' kvality prenosu od nepriaznivého počasia

Reálne poskytované služby širokopásmového prístupu kinternetu umožňujú využívanie nasledovného rozsahu rýchlostí prenosu:

- downstream $512 \mathrm{kbit} / \mathrm{s}$ až $48 \mathrm{Mbit} / \mathrm{s}$

- upstream $64 \mathrm{kbit} / \mathrm{s}$ až $256 \mathrm{kbit} / \mathrm{s}$. 
Širokopásmový prístup prostredníctvom družicových sietí nehrá v súčasnej dobe významnú úlohu v pripojení domácností. Vzhl'adom na svoju cenu a d'alšie parametre je využívaný vel'kými a strednými podnikmi v miestach, kde sú iné možnosti širokopásmového prístupu vel'mi obmedzené alebo žiadne. Možnú zmenu v kvantite poskytovanie tohto prístupu možno očakávat' v dohl'adnom čase vzhl'adom na nové aktivity Európskej agentúry pre vesmír (ESA).

\section{Družicová VSAT siet’}

VSAT (Very Small Aperture Terminal) stanica je vzdialený terminál v družicovej komunikačnej sieti. Ide o pozemnú stanicu s anténou s malým priemerom. Samotná komunikácia medzi jednotlivými VSAT stanicami je umožnená prenosom cez družicu, čo je opakovač, ktorý odráža prijatý signál zo Zeme, a aj preto môže byt' vzdialenost' medzi jednotlivými VSAT stanicami aj niekol'ko sto kilometrov.

Komunikácia medzi dvoma VSAT stanicami sa uskutočňuje vždy cez centrálnu stanicu. Vysielajúca VSAT stanica vysiela údaje do centrálnej stanice a centrálna stanica zase vyšle údaje do prijímacej VSAT stanice, čiže komunikácia sa realizuje vždy cez družicu. Príkladom takejto architektúry je družicový systém pre distribúciu televízie a rozhlasu.

\section{Mobilné siete}

HSCSD (High Speed Circuit Switched Data) - je technológia prenosu dát cez mobilnú siet' na princípe prepínania okruhov, ktorá je štandardom sietí $2.5 \mathrm{G}$ siete. Je určená pre pripojenie k sieti prenosovou rýchlost'ou až 43,2 kbit/s, a aj ked' technológia HSCSD využíva súčasnú siet' GSM, doplnením softvéru pre jej prevádzku o HSCSD dokáže prenášat' dáta až tri krát rýchlejšie ako bežnou GSM siet'ou.

Tretia generácia mobilných sietí UMTS (Universal Mobile Telecommunications System) ponúka širokopásmový prístup $384 \mathrm{kbit} / \mathrm{s}$, v prípade účastníka na pevnom mieste umožní rýchlost' až $2 \mathrm{Mbit} / \mathrm{s}$. Výraznou charakteristikou týchto širokopásmových služieb je ich poskytovanie mobilným uživatel'om, čo do značnej miery predurčuje charakteristiku príslušného segmentu trhu. Siet' UMTS umožňuje poskytovanie širokopásmového prístupu s obmedzením rýchlosti prenosu, ktoré je závislé od fyzikálnej rýchlosti, resp. od „mobility“ uživatel'a služby.

HSDPA (High Speed Data Packet Access) výrazným spôsobom posúva možnosti mobilných sietí tretej generácie UMTS. Vd’aka tejto technológií je možný prvý skutočne mobilný širokopásmový internet na Slovensku s názvom Orange internet expres. Nová dátová HSDPA siet' Orangeu podporuje okamžite dátové prenosové rýchlosti do 3,6 Mbit/s. Orange ponúka bezkonkurenčne najlepšie pokrytie signálom HSDPA, ktorý pokrýva všetky slovenské mestá nad 20 tisíc obyvatel'ov. Okrem toho môžu zákazníci Orangeu okamžite využívat' širokopásmový internet aj u vybraných roamingových partnerov.

FLASH-OFDM je jeden $z$ d'alších variantov mobilného širokopásmového internetového prístupu. Prvá plošná komerčná prevádzka siete FLASH-OFDM bola spustená na Slovensku v októbri 2005, firmou T-Mobile. Bezdrôtová technológia prenosu dát FLASHOFDM pracuje na Slovensku v pásme $450 \mathrm{MHz}$, ktoré bolo predtým využívané pre technológiu NMT. Na tejto frekvencii má bezdrôtový signál dobré podmienky na šírenie cez prekážky, ako sú terénne nerovnosti, budovy, steny a podobne. Technológia umožňuje 
komunikáciu aj pri nízkej úrovni signálu a rovnomernú del'bu prenosovej rýchlosti medzi užívatel'mi.

\section{Technológia cez optické vlákna}

Širokopásmový prístup na báze optických sietí je bezkonkurenčný vzhl'adom na možnú kapacitu a spol'ahlivost', ktoré zaručujú vysokú kvalitu i náročných multimediálnych aplikácií. Vel'kou výhodou je aj jednoduchost' siet’ovej architektúry, vysoká životnost' optického kábla i jeho odolnost' voči elektrickému rušeniu, t.j. náklady na údržbu samotnej infraštruktúry optickej siete. Optický prístup na rozdiel od rádiového prístupu nie je obmedzený dostupnost'ou frekvenčného spektra ani procesom pridel'ovania individuálnych povolení.

Ide o perspektívne riešenie poskytovania najnáročnejších multimediálnych širokopásmových služieb. Rýchlost' budovania optických prístupových sietí obmedzuje investičná náročnost'. Aj optický prístup má svoje nevýhody. Vzhl'adom na svoje vlastnosti je cenovo náročný, tiež má nevýhodu nižšej flexibility oproti bezdrôtovému prístupu.

\section{Wireless Fidelity (WiFi)}

WiFi alebo aj Wireless Fidelity je bezdrôtová technológia prenosu dát. WiFi používa pri prenose dát mikrovlny a vysiela $\mathrm{v}$ určenom pásme, ktoré je vyčlenené regulačným orgánom a $\mathrm{v}$ tomto pásme môžu vysielat' hromadné oznamovacie prostriedky ako televízie a rádia. WiFi svojim užívatel'om ponúka hned' niekol'ko výhod: vytvorit' si siet' l'ahko a rýchlo, bez nutnosti t'ahat' káble. Pôvodným zámerom bolo vystavat' siet' aj tam, kde je nemožné alebo ekonomicky nevýhodné stavat' klasické káblové siete, napríklad z bytu do bytu, z domu do domu, v historických budovách alebo rozsiahlych objektoch.

Momentálne na Slovensku WiFi používajú hlavne poskytovatelia alternatívneho pripojenia na internet, d'alej na miestach, kde sa často mení usporiadanie počítačov, napr. konajú sa porady manažmentu firmy.

\section{Pevný širokopásmový prístup v SR}

V súčasnosti nie sú všetky technológie umožňujúce širokopásmový prístup na území SR bežne prevádzkované. Z hl’adiska dostupnosti technológie DSL patrí v súčasnosti medzi najrozšírenejšie technológia ADSL.

V súčasnej dobe sa na území SR prevádzkujú pevné širokopásmové prístupové siete postavené na technológiách ADSL (T-Com, GTS Nextra, Slovanet, Swan, Dial Telecom, eTel, MBC, Amtel), DOCSIS (UPC Broadband) a Ethernet (Železničné Telekomunikácie). ADSL prístupovú technológiu prevádzkuje niekol'ko spoločností, ale výlučne na DSL prípojkách spoločnosti Slovak Telekom (ST), čiže účastnícka prípojka je plne pod správou ST. Prakticky všetci používatelia ADSL technológie sú pripojení na DSLAMy spoločnosti ST. Problémom v súčasnosti je neochota ST inštalovat' zariadenia DSLAM aj do vidieckych oblastí. Dôvody pre toto správanie sú nielen ekonomické (vyššie náklady na inštaláciu a nižšia návratnost' investícií), ale sú taktiež spôsobené neochotou inštalácie zariadení DSLAM pre nižší počet účastníkov. 
Spoločnost' Slovanet je jedným z najväčších poskytovatel'ov internetových a telekomunikačných služieb na Slovensku, zároveň je jedným z najprogresívnejších operátorov na trhu, ktorý sa silne angažuje pri presadzovaní nových technológií a bojuje proti monopolnému správaniu sa ST.

Internetová služba chello, ktorá je v súčasnosti sprístupnená pre 270000 domácností v 10 mestách Slovenska, od spoločnosti UPS, rozšíri svoje pokrytie od decembra o d'alšie mesto. Služba chello tak je sprístupnená v 11 nasledovných mestách: Bratislava, Trnava, Žilina, Poprad, Košice, Pezinok, Banská Bystrica, Nové Zámky, Dunajská Streda, Šamorín a Zvolen. Spoločnost' UPC bude v budúcom roku pokračovat' v sprístupňovaní internetu chello v d'alších lokalitách.[3]

Čo sa optických sietí týka, tie sa z hl'adiska perspektívy do budúcnosti, z pevných prístupových technológii, zatial' javia ako najvhodnejšie. Spoločnost' Orange spustila (3.9. 2007) prevádzku optickej siete, ktorá ponúka rýchlosti 60/8 Mbps. Medzi vybrané lokality, kde sa je už optika vybudovaná je Bratislava, Trnava, Piešt’any, Nitra, Trenčín, Žilina, Banská Bystrica a Prešov, Košíce, Prievidza a Nové Zámky.

Spoločnosti T-Com sa podarilo do konca roku 2007 pokryt' optickou prístupovou siet'ou 100- tisíc domácností a do konca roku 2008 plánuje rozšírenie o d’alších 100-tisíc až 200-tisíc domácností, v závislosti od finančnej návratnosti investície. Operátor plánuje poskytovat' dva typy optického pripojenia: FTTH, pri ktorom optické vlákno končí až v byte zákazníka (až odtial' sa môže viest' ethernetom) a FTTB, pri ktorom končí po vstupe do bytovej jednotky.

\section{Bezdrôtový širokopásmový prístup v SR}

Čo sa týka stavu technológií bezdrôtového širokopásmového prístupu na území SR, medzi najviac používané patrí mobilný prístup a WiFi. SR má z morfologického hl'adiska pomerne rôznorodé podmienky pre aplikáciu bezdrôtových technológii širokopásmového prístupu. Je pravdepodobné, že pokrytie hornatej časti SR a pokrytie rovín a nížin južného Slovenska bude vyžadovat' alebo použitie rozdielnych technológií, alebo prinajmenšom rozdiely v aplikácii určitej technológie.

Mobilný prístup poskytujú traja operátori- Orange, T-Mobile a O2. Všetky ponúkajú širokopásmový bezdrôtový prístup s rôznym pokrytím SR a s rôznymi rýchlost’ami. Najviac využívanými technológiami v SR sú EDGE a UMTS.

Už viac ako tri roky môžeme na Slovensku využívat' technológiu EDGE, ktorá vo svojej dobe priniesla hlavne výrazné zvýšenie rýchlosti mobilného pripojenia. Priemerná rýchlost' EDGE bola okolo $100 \mathrm{kbps}$, a tak často deklarované maximá 236,8 kbps pre download a 118,4 kbps pre upload boli takmer nedosiahnutel'né. Neskôr ale kvôli obrovskému množstvu použivatel'ov bola siet' často pret'ažená, pripojenie padalo a rýchlost' sa v mnohých prípadoch blížila dokonca $\mathrm{k}$ štandardným rýchlostiam GPRS. Za tento problém boli zodpovedné aj koncové zariadenia. EDGE na Slovensku využívajú všetci traja mobilní operátori.

Technológiu UMTS/HSDPA Orange zaviedla 3G systém UMTS už v roku 2005, získala tak určitý náskok v pokrytí pred spoločnost'ou T-Mobile, ktorá zaviedla technológiu širokopásmového prístupu Flash-OFDM spoločnosti Flarion. Výhodou tohto riešenia je 
pomerne dobré pokrytie SR. Vel'kou výhodou tejto technológie je jednoduchost' inštalácie a výborné hodnoty latencie a priemernej rýchlosti.

Technológiu WiMAX je na území SR možné využívat' od roku 2005, kedy boli pridelené TÚ SR štyri licencie na prevádzkovanie FWA v pásme 3,5 GHz (Amtel Slovensko, GlobalTel, Telenor Networks a WiMax Telecom).[4] Všetky spoločnosti majú vybudované WiMAX siete vo všetkých krajských a vybraných okresných mestách. Pokrytie je teda orientované na väčšie mestá s predpokladaným vel'kým prevádzkovým zat’ažením, vidiecke oblasti sú pokryté len minimálne.

\section{Záver}

Elektronické komunikačné systémy, súvisiace siet'ové infraštruktúry vrátane celosvetového fenoménu Internetu vytvárajú vel'ké predpoklady k poskytovaniu aplikácií a služieb, ktoré boli v minulosti alebo vôbec nepredstavitel'né, alebo si vyžadovali vel'ké časové a finančné náklady. Takéto nové možnosti majú zásadný dosah na celkovú ekonomiku a trendy rozvoja spoločnosti. Sú rozhodujúce pri modernizácií jednotlivých odvetví, prispievajú k vytváraniu nových pracovných príležitostí a tak vytvárajú technologické predpoklady pre novú znalostnú ekonomiku.

Širokopásmové komunikácie hrajú významnú rolu pri modernizácii ekonomiky a spoločnosti. Kl'účové pri ich realizácií sú moderné informačné a komunikačné technológie (ICT). Využívanie moderných ICT vedie $\mathrm{k}$ vyššej produktivite, vyšším príjmom, k zvyšovaniu počtu firiem schopných konkurencie na trhu a v konečnom dôsledku väčším zdrojom do ekonomiky, ale zároveň na druhej strane kladie nároky na zmeny fungovania spoločností a investície do vzdelávania.

\section{Literatúra}

[1] História a vývoj DSL. Dostupné na: <http://www.pripojsa.sk/?page=historia-a-vyvoj$\operatorname{dsl} />$

[2] MURÍN, V., PLINTOVIČOVÁ, D., BIBA, J., Význam a využitie širokopásmového prístupu na internet. 2006. Výskumný ústav spojov, n.o., Banská Bystrica, 2006. Dostupné na:

$<$ http://www.vus.sk/broadband/nbbs/VUSBB_PPP_SF_11_2006fin.pdf>

[3] KOLÁR, J., Triple Play od UPC využíva už 10000 zákazníkov. 2008. Dostupné na: $<$ http://www.upc.sk/o_upc/tlacove_spravy>

[4] Žilinská univerzita v Žiline., Širokopásmový prístup v SR. 2006. Žilinská univerzita. Žilina, 2006. Dostupné na:

$<$ http://www.telecom.gov.sk/index/open_file.php?file=telekom/vyskum/projekty/2006 /01_sirokopasmovy_pristup.pdf

\section{Grantová podpora}

Článok je súčast'ou riešenia úlohy Zvýšenie atraktívnosti vysokej školy prostredníctvom marketingovej komunikácie vzdelávacej inštitúcie - KEGA 3/5030/07. 